\section{Why school psychology for diversity?}

\author{
Paul A. Bartolo
}

University of Malta \\ (C) The Author(s) 2010 \\ Reprints and permissions: \\ sagepub.co.uk/journalsPermissions.nav \\ DOI: $10.1177 / 0143034310386532$ \\ spi.sagepub.com
}

\begin{abstract}
This article discusses the dilemma faced by psychologists in responding to diversity. It is based on a qualitative review of relevant literature over the past decade. It first describes psychologists as frontrunners in recognizing the uniqueness and autonomy of each of their diverse clients but within the biomedical model that locates problems within clients. This raises a dilemma vis-à-vis diversity issues which are associated with discrimination suffered by minority groups who are best supported by changes in social structures and processes. An account is then given of an increasing adoption of a biopsychosocial model, with further influence of the social model of disability and mental health. Evidence of the trend is explored in a new commitment to the human rights agenda, changes in ethical codes, and in psychologists' engagement with intervention at macro systems levels as in the promotion of inclusive education. The review concludes with the implications of these trends for greater changes in training institutions to reflect openness to diversity, and in training programmes to promote an understanding of, and skills in, using social approaches to addressing the needs of clients who are at risk of being misunderstood, devalued, and discriminated against.
\end{abstract}

\title{
Keywords
}

biopsychosocial model, diversity, inclusion, inclusive education, multicultural competence, social justice

\section{Introduction}

Diversity related research is on the rise (Brown, Shriberg, \& Wang, 2007), and the term 'celebrating diversity' has become a cliché (Benjamin, 2002). This is one reason for raising the theoretical question of why and how psychologists need to be concerned about diversity. There are at least three other reasons. First of all, diversity issues call for action for social change which remains a dilemma for professional psychologists who are often seen as concerned with change in individuals only

\section{Corresponding author:}

Paul A. Bartolo, University of Malta, Msida MSD 2080, Malta

Email: paul.a.bartolo@um.edu.mt 
(Gilbert, 2009), a dilemma that will be the focus of this article. Secondly, we need to ask the question because responding to diversity involves to a large extent a change of attitudes and perspectives (American Psychological Association [APA], 2002) that in turn call for reflective questioning (Park-Taylor et al., 2009). The third reason, particularly from an international perspective, is because it is understood that there are different answers to this question coming from different contexts within and across countries and cultures (e.g. Fearnley-Sander, Moss, \& Harbon, 2004).

\section{Human diversities}

Seventeen personal and social categories of difference are identified in the Charter of Fundamental Rights of the European Union as presenting risks for discrimination, namely:

sex, race, colour, ethnic or social origin, genetic features, language, religion or belief, political or any other opinion, membership of a national minority, property, birth, disability, age or sexual orientation. (Charter of Fundamental Rights of the European Union, 2000, Art. 21)

This article refers to two major categories that subsume some of the above and have been the focus of most diversity theory and research in education and psychology, namely disability (e.g. APA, 2009) and multiculturalism (e.g. Esquivel, Lopez, \& Nahari, 2007). For instance, in a review of research on teacher education, the authors found it appropriate to analyse in two separate chapters research on 'preparing teachers for diverse populations' and on 'preparing general education teachers to work with students with disabilities' (Cochran-Smith \& Zeichner, 2005).

These issues are often also mixed with challenges faced by children from backgrounds of poverty. Poverty is itself an international issue with millions still not yet having access to schooling at all (United Nations Educational, Scientific and Cultural Organization [UNESCO], 2009). While each category of disadvantaged groups has its particular concerns in particular contexts, countries, and times, one can see them all as giving rise to situations where a minority or disempowered group is at risk of being misunderstood and discriminated against by the dominant group (Block, Balcaza, \& Keys, 2001; David, 2009).

Discrimination and social justice are human rights issues that lie in the arena of politics. This article raises the question of why and how they have also become major concerns of psychology and particularly education and school psychology.

\section{Method}

This is a theoretical article based on a qualitative review of the relevant literature over the past ten years. Two literature clusters were explored, namely the engagement of psychology with disability issues and with multicultural issues. This article 
is an attempt to combine the two issues under the common one of psychology and social justice. In order to locate the relevant literature, the following keyword searches were conducted, first on literature databases listed in EBSCOhostAcademic Search Complete, ASSIA, ERIC, IngentaConnect, PsycINFO, and PubMed, and then also on Google: 'psychology and diversity/social inclusion/ social justice/disability/multicultural', 'multicultural competence training', 'diversity training', 'disability and inclusion', 'school/educational psychology and inclusion'. Relevant thinking and text extracts were thematically analysed, also with reference to the authors' professional experience in this area (see e.g. Bartolo, 2008, 2010). These were developed into the themes that are discussed below, namely (a) the balancing of the individualist versus the ethics-of-care perspectives of human development and well-being; (b) the implications of the biopsychosocial and social constructivist models in psychology and the social model of disability; (c) the reflection of these newer perspectives in new developments on ethical standards for psychologists; (d) how these developments are reflected in newer perspectives on inclusive education in school psychology; and finally (e) how these developments are reflected in the training of psychologists.

\section{Psychologists for diversity and individualism-a dilemma}

Psychologists are in one way forerunners in appreciating the uniqueness of individuals while at the same time being latecomers to the notion of supporting individuals by working for social change.

\section{Respect for the individual}

As professionals working in close interpersonal interaction with individuals, psychologists have always been most able to appreciate the uniqueness of individuals. This is reflected very strongly in all ethical codes for psychologists under the principle of 'Respect for a Person's rights and dignity' (EFPA, 2005):

Mental health professionals respect the right of individuals, as autonomous agents, to make their own decision and behavioral choices regarding how they wish to conduct their lives;... we acknowledge their right to act on even their idiosyncratic and irrational personal preferences, as long as their behavior does not infringe upon the legal rights of others. (Ford, 2006, p. 33)

Most western psychologists subscribe to the idea of the good life as self-fulfilment (Christopher \& Hickinbottom, 2008) and to the Gestalt prioritizing of individual autonomy (Crocker, 1983; Perls, 1969). Psychological therapies have for long highlighted the importance of a non-judgemental attitude to clients whatever their diverse characteristics, beliefs, or values. In this sense, psychologists are urged to reflect on their own values. Thus the first guideline for the development of multicultural competence encourages psychologists 'to recognize that, as 
cultural beings, they may hold attitudes and beliefs that can detrimentally influence their perceptions of and interactions with individuals who are ethnically and racially different from themselves' (APA, 2002).

\section{The contrasting biopsychosocial model}

Though seeming to be diversity friendly, the above individualistic approach is still focused on within person processes. It does not include, and may indeed present a dilemmatic position vis-à-vis the socio-cultural perspective reflected in the ethics of care (Slote, 2007). The latter is based on the now wide psychological understanding that individual human welfare is also closely tied to the ecological system in which one lives and grows (Bronfenbrenner, 1979) and that, as the growing field of cultural psychology demonstrates, "the psyche is not a discrete entity packed in the brain. Rather, it is a structure of psychological processes that are shaped by and thus closely attuned to the culture that surrounds them' (Kitayama \& Cohen, 2010, p. xiii). The ethics of care are based on the principle that human development and its potential distortion are the result of a biopsychosocial process (Cooper \& Olsen, 2001; White, 2005) that calls for intervention at the social as well as individual levels.

As psychologists in education, we are aware of the psychological and social constructivist approaches to development often associated with Piaget and Vygotsky. Many practitioners themselves and the general public expect psychologists to be experts in 'entering the child's mind' (Ginsburg, 1997). The Piagetian constructivist approach to education is regarded as a progressive child-centred approach which sees the purpose of education as teaching the individual child in a fashion that supports the child's interests and needs, with an emphasis on individual cognitive development and the assumption that development is 'an ingrained, natural, biological process that is pretty much the same for all individuals, regardless of gender, class, race, or the social or cultural context in which learning and living take place' (Abdal-Haqq, 1998).

However, many school psychologists gradually come to realize that the above approach only partially addresses the learning challenges of children coming from deprived backgrounds or minority cultures. The individual approach alone has not helped children in schools from low socio-economic backgrounds (see Vavrus \& Dllworth, 2002). The challenge for such children is better understood through the social constructivist approach to education which 'locates the individual within a cultural milieu and identifies the subject of study as the dialectical relationship between the two... Constructivist pedagogical approaches must consider the larger social climate in order to develop in a manner that is culturally relevant and socially just' (Vadeboncoeur, 1997, pp.15-16). The case has also been made for the impact of the social environment even in areas where the biological basis of the impairment has not been in doubt such as ADHD and Asperger Syndrome. Thus Cooper and Olsen (2001) refer to these impairments as 'a particular biological tendency' that does not necessarily doom an individual to a determined pattern of life and behaviour: 'Rather the biopsychosocial approach highlights potential 
risk factors that can be averted through intervention ... with biomedical intervention being only seen as an adjunct to these [psychological, social, and educational factors]' (p. 7). Resilience studies have also highlighted the fact that healthy human development for all, including those in otherwise adverse environments, is closely tied to compensatory environmental protective factors, often being the family and/ or other external systems such as the school and the classroom (Benard, 2004; Cefai, 2008).

\section{The social model of mental illness and disability}

Within mental health, too, there has been a gradual impact by the findings of sociologists - and of social psychologists - on the social construction of illness, disability and disadvantage. Even within psychiatry there is an increasing recognition of the significant impact of stigma on the welfare of persons with mental illness (Leff \& Warner, 2006): 'Recent research indicates that socio-environmental factors are implicated in the etiology of schizophrenia as well as influencing its course' (Leff, 2008, p. 2). Within psychology itself, the development of critical psychology has been the most revealing of the need for a change in approach for psychology to serve social justice and human welfare. It has been argued that:

- by focusing on the individual rather than the group and larger society, mainstream psychology overemphasizes individualistic values, hinders the attainment of mutuality and community, and strengthens unjust institutions;

- mainstream psychology's underlying assumptions and institutional allegiances disproportionately hurt members of powerless and marginalized groups by facilitating inequality and oppression; and

- these unacceptable outcomes occur regardless of psychologists' individual or collective intentions to the contrary. (Fox, Prilleltensky, \& Austin, 2009, p.5)

At the practitioner level, the above understanding has been the motivation for the development of community psychology which tries to address the social aspects of mental health (Orford, 2008; Webster \& Robinson, 2007). Given the the established links 'between poor mental health and poverty, poor community integrations, and the competitiveness of groups', Gilbert (2009) raised the question 'as to whether we should be working with individuals at all or with communities' ( $\mathrm{p}$. 402). In the UK, community psychology is coming together with the longer established socially focused work of systemic therapy under the umbrella of 'multi-systemic therapy' which is currently indicated to compensate for social exclusion:

Multi Systemic Therapy (MST) is a family and community-based treatment programme for young people with complex clinical, social, and educational problems 
such as violent behaviour, drug abuse and school expulsion. MST therapists work in close partnership with the young person's family and community to strengthen protective factors known to reduce the risk of future offending and anti-social behaviour. (Cabinet Office, UK, 2009, webpage on MST)

Within disability studies, the social model developed in the UK by persons with physical disability has been a very radical proposition against the medical model that focused on within-individual deficits. One of the most radical statements was Oliver's (1990) description of 'conductive education', which many had hailed as a new hope for children with physical disability, as instead being 'an oppression':

The current popularity of 'conductive education' is a product of this ideology of the able-bodied individual, for its aim is to teach children with cerebral palsy to walk, talk and engage in all other activities in as near normal way as possible. No consideration is given to the issue of the ideology of 'normality' nor to the idea that the environment could be changed rather than the individual. And scant regard is paid to the costs involved in terms of pain, coercion, loss of childhood, disruption of family life, acceptance of alternative ways of doing things and so on. (Oliver, 1990, pp. 55-56)

Oliver's radical view has come under considerable criticism (e.g. Shakespeare \& Watson, 2001). However, his insistence to give a voice to disabled people themselves, and to measure social justice and inclusion by the level of participation that society affords people who are different, has had a most important impact on national and educational policies of inclusion (e.g. Booth \& Ainscow, 2002).

\section{Psychology against discrimination and for human rights}

Psychologists have always been sensitized to the need for social change when discriminatory systems infringed on the rights of individuals. This responsibility towards the development of healthy social structures has come home to western psychology through the exposure of extremely abusive situations, such as the impact of child sexual and physical abuse, and more recently through the important learning moment created by the use of torture on prisoners. A majority of psychologists in the American Psychological Association agreed to pass the 'Resolution Against Torture and Other Cruel, Inhuman, or Degrading Treatment or Punishment' recommending that psychologists should not participate in the administration in settings where any form of torture is involved (APA, 2006).

An earlier reaction to the same use of torture by administrations had led the British Psychological Society to hold its first conference on Psychology and Human Rights which 'demonstrates the commitment of the Society to this important area 
of work' (Inaugural Meeting, 2005). The convenor explained that psychologists, who deeply understood human basic needs and human relationships, were most able to understand human rights which are 'formalised systems ensuring the respect for the satisfaction of basic human needs' and 'the legal codifications of how we collectively understand our relationships and obligations to each other' (Kinderman, 2005).

Psychologists are indeed very well placed to understand the impact of prejudice and discrimination on the lives of individuals and groups, particularly children, be they the victims of physical, sexual or emotional abuse, as well as of social exclusion on the basis of ethnic membership, socio-economic status, ability, gender, sexual orientation, religion, or disability.

Moreover, the idea that socially unjust structures are the source of frequent human suffering has been taken up strongly by some psychologists. Over the past 25 years, various organizations of psychologists were formed dedicated to socio-political action and they came together as an 'International Network of Psychologists for Social Responsibility' that 'use psychology to understand and address pressing social issues' (International Network of Psychologists for Social Responsibility [INPsySR], 2009).

\section{Psychologists for social responsibility}

The above developments have recently been reflected in developments on ethical standards for psychologists which now extend psychologists' responsibility to the societal level. In the recent attempt to develop a 'Universal Declaration of Ethical Principles for Psychologists', the first most fundamental principle is stated in relation to 'Respect for the Dignity of Persons and Peoples' (the latter term was introduced to replace the previous term 'others') (Gauthier, 2008). This is seen as implying among other things:

c) respect for the customs and beliefs of cultures, to be limited only when a custom or a belief seriously contravenes the principle of respect for the dignity of persons or peoples or causes serious harm to their well-being;.... .

g) fairness and justice in the treatment of persons and peoples. (Gauthier, 2008, p. 6)

There is an explicit reference here to psychologists' responsibility to the welfare of groups as well as individuals. Whereas in the European Meta-code for psychologists (EFPA, 2005), the terms 'social' or 'society' do not occur at all, and the word 'community' is only used once for the 'psychological community', the Universal Declaration makes 'society' as part of the title of one of its principles, and refers to society as 'collective peoples' as different from the individual (Gauthier, 2008, p. 6). In its fourth principle on 'social responsibility', the draft Universal Declaration requests psychologists to work at the development of 'social structures and policies that benefit all persons and peoples'. 


\section{School psychologists for diversity?}

Within education, school psychologists have experienced the above developments very strongly (Farrell, 2006). The traditional perspective on psychologists as being associated with diagnosing deficits in children and recommending placement for special schooling is still alive. In her introduction to a special issue on 'Special and inclusive education in the Mediterranean', Phtiaka, the guest editor sociologist, identified psychology as 'the undisputed queen of special education' leading to 'pathological interpretations of disability and special education':

Given its very nature, psychology has naturally concentrated on the individual and what has been considered an individual problem. When and where abused, this has led to a pathological interpretation of disability and special education, which have in turn led to a fatalistic attitude about what can be achieved 'given a child's IQ test' or later 'his/her pathological environment'. (Phtiaka, 2001, p. 7)

She saw this author's own article on inclusive education as - 'unusually - much more interested in education policy rather than traditional "psychological pursuits" in special education', and as evidence of a shift towards 'other approaches more than the traditional medical model' (p. 7).

In Malta, school psychologists have been influenced by sociological approaches to disability. These approaches had been presented most forcefully to the Maltese community of health and education professionals 17 years ago at a national special education policy conference by the sociologist Len Barton (1993): he had argued that the issue of disability should be recognized 'as a human rights issue and not one which relies on charity or favours of powerful groups' (p. 20).

This approach is now widely understood to be the appropriate one to take in the face of all forms of discrimination in educational opportunities (UNESCO, 2005). It has been also strongly taken up worldwide within school psychology. ISPA has been particularly dedicated to the human rights framework, it being the only psychology NonGovernmental Organizsation listed as a member of the NGO Group for the Convention on the Rights of the Child (CRIN, no date): 'ISPA has thus made children's human rights a high priority in its international work during the last decade and will maintain this emphasis in the future' (ISPA, Mission Statement).

Similar developments across the world may also be observed. For instance, the Task Force on Psychology in the Education System of the European Federation of Psychologists' Associations (EFPA) declared the first of two principles underlying the work of psychologists as being 'Children's Rights' following the UN Convention:

The TF wants to emphasise the right of all children to receive education. This not only includes making education available to all, but also obliges governments to take all appropriate measures to create an optimal learning environment ... Education should 
be directed towards the development of respect for the child's parents, his or her own cultural identity, language and values, for the national values of the country in which the child is living, the country from which he or she may originate, and for civilisations different from his or her own.... (EFPA, 2001, para 4.3.1)

The EFPA Task Force has also for long recognized that an essential part of the work of 'psychologists in the education system' is work at systems level. It described the work of psychologists on prevention, evaluation, and intervention at the four levels of 'society, the school system, groups, and the individual' (EFPA, 2001, para 4.4.2).

The same approach is recommended in the model for comprehensive and integrated school psychological services of the National Association of School Psychologists' (NASP), as for example:

School psychologists function as change agents, using their skills in communication, collaboration, and consultation to promote necessary change at the individual student, classroom, building, and district, state, and federal levels. (NASP, 2010, p. 5)

School psychologists use their knowledge of organizational development and systems theory to assist in creating climates that result in mutual respect and caring for all individuals in the system, an atmosphere of decision-making and collaboration, and a commitment to quality services. (NASP, 2010, p. 6)

\section{Balancing the dilemma}

The traditional and more recent roles of psychologists often create practical dilemmas for many school psychologists. One might be faced for instance, with addressing a situation where hearing impairment requires a child to use sign language which is cutting him off from mainstream peers. Should the focus be on teaching the child to communicate with his/her non-hearing impaired peers or should the teacher and whole class be asked to learn sign language so that they can understand him/her?

When the concern is to help the particular child, as is often the case in psychologists' direct work with children, one useful approach that has been proposed is what has been termed a 'compensatory interaction model' (Wedell, 1995). Rather than simply adopt exclusively either the medical or the social models, one has to consider the fit between the strengths and weaknesses within the child with the strengths and weaknesses within the environment. Thus, referring again to the situation of the child with hearing impairment: (a) one can support the child to change and learn the ways of the 'normal' world such as through lip reading if that is a possibility for that particular child, and (b) at the same time work towards changing the world so that being a sign language user does not constitute a barrier 
to participation by introducing the class to the levels possible in sign language, and thus creating supportive communities in which each learner is equally understood, valued and respected and provided with a quality education and life experiences.

Similarly, while working to enhance resilience skills in children coming from poverty backgrounds, one has to work with equal vigour to change the structures that reinforce the cycle of poverty.

\section{Implications for training}

The implications of the new trends in psychology are that psychologists must not only be trained to help individuals achieve desirable changes, but they must equally be trained in understanding the impact of social environments and in work towards social change. Two major approaches have been used in such training (Bartolo \& Smyth, 2009), namely that the training institution itself should be a model of respect for diversity in its structure and processes; and secondly that the psychologist training programme should increase trainees' awareness of the potential for discrimination and enhance their skills in working with diverse clients and diverse social contexts.

Maybe the best illustration of the first principle mentioned above, relates to the reason why the election of President Obama was deemed as a historic step in race relations in the USA. It is the equal participation of different cultural groups in the structures of power that is the strongest sign of equal opportunity and status for all groups. Indeed the APA in the US have been leaders in identifying and addressing the issue through the APA Office of Ethnic Minority Affairs (OEMA) and later Commission on Ethnic Minority Recruitment, Retention, and Training (see CEMRRAT2, 2006, 2008) since 1979.

Of course the situation in the EU and countries across the world is related to the existing circumstances. But it is important that training institutions are sensitive to the issue. This includes concerns with diverse gender, ethnic, and religious diversity among the trainers.

With regards to the second concern of infusing diversity into the programme content, again training institutions may not as yet have incorporated the social justice approaches within their course framework, thus emphasizing 'individual-level functioning instead of broader social, cultural, and political forces' (Meyers, 2007).

Various strategies for the development of social justice competences in trainee psychologists have been used. Invariably one of them has been that of enabling trainees to become aware of their own cultural baggage, as observed in teacher education research (Bartolo \& Smyth, 2009). This should be incorporated in the personal therapy sessions that should be part of their training, but needs to be also an essential aspect of units on intercultural competency training (see Cushner, 2006).

The other research pointer is that there is also a need to incorporate social justice approaches in fieldwork (Amodio, Devine, \& Harmon-Jones, 2008). In a meta-analysis of such an approach, Jacobs (2006) found that researchers reported challenging supervision of practice as more effective than engaging in discussion 
about social justice in society or schools in general. Fieldwork also needs to address working at systems level.

Finally, school psychologists are well placed to be proactive in the training of other professionals in ensuring diversity enriches people's lives:

Psychologists are in a position to provide leadership as agents of prosocial change, advocacy, and social justice, thereby promoting societal understanding, affirmation, and appreciation of multiculturalism against the damaging effects of individual, institutional, and societal racism, prejudice, and all forms of oppression based on stereotyping and discrimination. (APA, 2002, p.15)

\section{Conclusion}

This article set out to highlight the increasing importance that psychologists in general, and school psychologists in particular, are giving to working for social change to ensure the well-being, growth and learning of their clients. It presented the dilemma experienced by psychologists who, on the one hand respect the diversity inherent in the uniqueness of their clients, while at the same time being wary of asking others to change for the sake of a client. This is balanced by the recent greater understanding of the impact of social structures and processes on the well-being of individuals and the social construction of human disability and disorders. Psychologists in general, and school psychologists in particular, are now seeing the promotion of equitable social structures and processes as an important dimension of their work. It is suggested that training programmes for psychologists should first ensure that the programme faculty and enrolment policies and practices reflect a respect for trainer and trainee diversity. Secondly, programmes need to ensure provision of multicultural self awareness training and understanding of the potential risk for discrimination against minority or disadvantaged groups, to be coupled with opportunities for developing intervention skills in bringing about change in social environments to enable valued participation of all members in the life of their communities.

\section{References}

Abdal-Haqq, I. (1998). Constructivism in teacher education: Considerations for those who would link practice to theory. ERIC Digest. Retrieved April 19, 2009, from http:// www.ericdigests.org/1999-3/theory.htm.

Amodio, D. M., Devine, P. G., \& Harmon-Jones, E. (2008). Individual differences in the regulation of intergroup bias: The role of conflict monitoring and neural signals for control. Journal of Personality and Social Psychology, 94, 60-74.

American Psychological Association (APA) (2002). Guidelines on multicultural education, training, research, practice, and organizational change for psychologists. APA. Retrieved March 18, 2009, from http://www.apa.org/pi/multiculturalguidelines.pdf.

APA Council of Representatives (2006b). Resolution against torture and other cruel, inhuman, and degrading treatment or punishment, August 9, 2006. Retrieved February 16, 2009, from http://www.apa.org/governance/resolutions/notortureres.html. 
APA (2009). Disability issues and psychology. From http://www.apa.org/pi/disability/

Bartolo, P. A. (2008). Preparing teachers for diversity. Maltese Review of Educational Research, 6, 1-14.

Bartolo, P. A. (2010). The process of teacher education for inclusion: The Maltese experience. Journal of Research in Special Educational Needs, 10(s1), 139-148.

Bartolo, P. A., \& Smyth, G. (2009). Teacher education for diversity. In A. Swennen, \& M. van der Klink (Eds.), Becoming a teacher educator (pp. 117-132). Netherlands: Springer.

Barton, L. (2003). Disability and special eduational needs: Some perennial European concerns. Education (Malta), 9, 17-22.

Benard, B. (2004). Resiliency: What we have learned. San Francisco, CA: WestEd.

Benjamin, S. (2002). Valuing 'diversity': A cliché for the 21st century? International Journal of Inclusive Education, 6, 309-323.

Block, P., Balcaza, F., \& Keys, C. (2001). From pathology to power: Rethinking race, poverty, and disability. Journal of Disability Policy Studies, 12, 18-27.

Booth, T., \& Ainscow, M. (2002). Index for inclusion: Developing learning and participation in schools (Rev. ed). Bristol: CSIE.

Bronfenbrenner, U. (1979). The ecology of human development: Experiments by nature and design. Cambridge, MA: Havard University Press.

Brown, S. L., Shriberg, D., \& Wang, A. (2007). Diversity research literature on the rise? A review of school psychology journals from 2000 to 2003. Psychology in the Schools, 44, 639-650.

Cabinet Office, UK (2009). Multi-sytemic therapy. London: CO, Social Exclusion Task Force. From http://www.cabinetoffice.gov.uk/social_exclusion_task_force/ multi_systemic.aspx.

Cefai, C. (2008). Promoting resilience in the classroom: A guide for developing pupils' emotional and cognitive skills. London: Jessica Kingsley.

CEMRRAT2 (2006). Task force proposed resolution justification statement. APA. From http://www.apa.org/pi/oema/justification_statement_resolution_minority.pdf.

CEMRRAT2 (2008). Progress report, portrait of success and challenge: 1997-2005: The APA/CEMRRAT plan for ethnic minority recruitment, retention and training in psychology. APA. From http://www.apa.org/pi/oema/CEMRRAT_progress_report_success_ challenges.PDF.

Charter of Fundamental Rights of the European Union (2000). Strasbourg: EU Parliament.

Christopher, J. C., \& Hickinbottom, S. (2008). Positive psychology, ethnocentrism, and the disguised ideology of individualism. Theory \& Psychology, 18, 563-589.

Cochran-Smith, M., \& Zeichner, K. M. (Eds.) (2005). Studying teacher education: The report of the AERA Panel on Research and Teacher Education. Mahwah, NJ: Lawrence Erlbaum Associates.

Cooper, P., \& Olsen, J. (2001). Dealing with disruptive students in the classroom. London: Routledge.

Crocker, S. F. (1983). Truth and foolishness in the 'Gestalt Prayer'. Gestalt Journal, 6, 4-15.

Cushner, K. (2006). Human diversity in action: Developing multicultural competencies for the classroom (3rd ed.). Boston, MA: McGraw Hill.

David, C. C. (2009). Intergroup attitudes and policy support: How prejudice against minority groups affects support for public policies. International Journal of Public Opinion Research, 21, 85-97. 
Esquivel, G. B., Lopez, E. C., \& Nahari, S. G. (2007). Handbook of multicultural school psychology: An interdisciplinary perspective. New York, NY: Lawrence Erlbaum.

European Federation of Psychologists' Associations (EFPA) (2005). Meta-code of ethics for psychologists. Granada: EFPA Council. From http://www.efpa.eu/ethics/ethical-codes.

EFPA Reports General Assembly (2001). From http://www.efpa.eu/reports/reports-generalassembly-2001.

EFPA Reports General Assembly (2005). From http://www.efpa.eu/reports/reports-generalassembly-2005.

Farrell, P. (2006). Developing inclusive practices among educational psychologists: Problems and possibilities. European Journal of Psychology of Education, 21, 293-304.

Fearnley-Sander, M., Moss, J., \& Harbon, L. (2004). Reading for meaning: Problematizing inclusion in Indonesian civic education. International Journal Of Inclusive Education, 8, 203-219.

Ford, G. G. (2006). Ethical reasoning for mental health professionals. Thousand Oaks, CA: Sage.

Fox, D., Prilleltensky, I., \& Austin, S. (Eds.) (2009). Critical psychology: An introduction (2nd ed). London: Sage.

Gauthier, J. (2008). The universal declaration of ethical principles for psychologists: Third draft. International Union of Psychological Science, International Association of Applied Psychology, International Association for Cross-Cultural Psychology. Retrieved May 31, 2009, from http://www.am.org/iupsys/resources/ethics/2008-universal-decl-report.pdf.

Gilbert, P. (2009). Moving beyond cognitive behaviour therapy. The Psychologist, 22(5), 400-403.

Ginsburg, H. P. (1997). Entering the child's mind. Cambridge: Cambridge University Press.

Inaugural Meeting: Psychology \& Human Rights (2005). http://www.bps.org.uk/events/ ac2005/docs/hr_programme.pdf.

International Network of Psychologists for Social Responsibility (INPsySR) (2009). http:// www.inpsysr.org.

Jacobs, J. (2006). Supervision for social justice: Supporting critical reflection. Teacher Education Quarterly, 33(4).

Kinderman, P. (2005). Psychological perspectives on human rights and British Psychological Society policy. Abstract, 'Inaugural Meeting Psychology and Human Rights: Programme and Proceedings'.

Kitayama, S., \& Cohen, D. (2010). Handbook of cultural psychology. London: Guilford Press.

Leff, J., \& Warner, R. (2006). Social inclusion of people with mental illness. New York, NY: Cambridge University Press.

Leff, J. (2008). Comment on Paper by Cohen, Patel, Thara, and Gureje. Schizophrenia Bulletin Advance Access, January, 21.

Meyers, S. A. (2007). Putting social justice into practice in psychology courses. APS Observer, 20(9), 1-5.

National Association of School Psychologists (NASP) (2010). Model for comprehensive and integrated school psychological services, 2010. NASP. From http://www.nasponline.org/ standards/2010standards/2_PracticeModel.pdf.

Oliver, M. (1990). The politics of disablement. London: Macmillan Education.

Orford, J. (2008). Community psychology: Challenges, controversy and emerging consensus. West Sussex: John Wiley. 
Park-Taylor, J., Kim, G. S., Budianto, L., Pfeifer, G., Laidlaw, P., Sakurai, M., \& Pfiefer, J. (2009). Toward reflective practice: A multicultural competence training model from a community mental health center. Professional Psychology: Research and Practice, 40, $88-95$.

Perls, F. (1969). In and out of the garbage pail. Lafayette, CA: Real People Press.

Phtiaka, H. (2001). Editorial introduction: Special and inclusive education in the Mediterranean at the beginning of the new millenium. Mediterranean Journal of Educational Studies, 6(2), 1-13.

Shakespeare, T., \& Watson, N. (2001). The social model of disability: An outdated ideology? Exploring theories and expanding methodologies. Research in Social Science and Disability, 2, 9-28.

Slote, M. (2007). The ethics of care and empathy. London: Routledge.

United Nations Educational, Scientific and Cultural Organization (UNESCO) (2005). Guidelines for inclusion: Ensuring access to education for all. Paris: Author.

United Nations Educational, Scientific and Cultural Organization (UNESCO) (2009). Policy guidelines on inclusion in education. Paris: Author.

Vadeboncoeur, J. A. (1997). Child development and the purposes of education: A historical context for constructivism in teacher education. In V. Richardson (Ed.), Constructivist teacher education: Building a world of new understandings (pp. 15-38). London: Routledge.

Vavrus, M. J., \& Dllworth, M. (2002). Transforming the multicultural education of teachers: Theory, research, and practice. New York, NY: Teachers College Press.

Webster, A., \& Robinson, M. (2007). Can community psychology meet the needs of refugees?. The Psychologist, 20, 156-158.

Wedell, K. (1995). Putting the Code of Practice into practice: Meeting special educational needs in the school and classroom. London: University of London, Institute of Education.

White, P. (2005). Biopsychosocial medicine: an integrated approach to understanding illness. Oxford: Oxford University Press.

Paul A. Bartolo is the Coordinator of the MPsy Professional Training Programme for Educational Psychologists at the University of Malta. He also coordinates the Programme for Culturally Responsive Education and the MEd for School Inclusion Coordinators. He led a National Curriculum Focus Group on Inclusive Education and a recent EU Comenius Project among higher education institutions from seven European countries which produced multilingual training materials for preparing teachers to respond to diversity (www.dtmp.org). He has published widely on educational psychology and inclusive education. He set up the school psychological services in Malta and has been consultant for accredited services for children with autism spectrum conditions. He was founder member and past president of the Malta Union of Professional Psychologists, and chair of the 31st ISPA Conference in Malta. 